\title{
Teachers' Attitudes towards Translanguaging in Indonesian EFL Classrooms
}

\author{
Khairunnisa \& Iwa Lukmana \\ Universitas Pendidikan Indonesia, Bandung, Jawa Barat, Indonesia \\ neesaannis@upi.edu, iwa.di.bandung@upi.edu
}

Naskah diterima tanggal 04/08/2020, direvisi akhir tanggal 15/08/2020, disetujui tanggal 30/08/2020

\begin{abstract}
This study aims to investigate the attitudes towards translanguaging in EFL classrooms by 50 English language teachers. The present study employed quantitative descriptive. A survey was administered to the teachers to gauge information regarding the importance of translanguaging use and the frequency with which these teachers felt it was practiced in the classroom. The survey was collected through questionnaire that included multiple-choice and Likert scale questions. The findings revealed that Indonesian EFL teachers showed positive attitude towards the use of translanguaging in their classrooms. Most of them considered the incorporation of Indonesian language and local language are beneficial in EFL classrooms. It is also discovered that Indonesian EFL teachers were flexibly use translanguaging to facilitate students' learning. Nonetheless, this study is limited to teachers' attitudes. Hence, further study is needed to observe translanguaging practices in Indonesian EFL classrooms.
\end{abstract}

Keywords: EFL classrooms, Teachers' attitudes, Translanguaging

\section{INTRODUCTION}

English in Indonesia is positioned as foreign language. The use of English in every day situation is still uncommon in Indonesia. This situation leads the teachers to provide appropriate approach for the students. In the context of education in EFL classroom, the use of English-only instruction and the incorporation of L1 are still debatable. In line with this, scholars have grown attention to the use of students' native language in the classroom to learn target language. It is believed that in L2 classroom, students are allowed to draw their native language repertoire in order to make connection between their dominant language and the one they are learning as well as to build on linguistic knowledge in order to become proficient speakers in English (Cook, 2001). The phenomenon being described is now labelled as translanguaging. Therefore, this phenomenon can be understood through the explanation of the concept of translanguaging, translanguaging pedagogy and relevant studies which will be described below.

In general, the concept of translanguaging means allowing students to use their native language repertoire to support language learning in target language classroom. It is firstly coined as "trawsieithu" and later translated into English as "'translanguaging" by Cen Williams in 1940 when he studied bilingual classroom in Welsh (Williams, 1996). He defined translanguaging as a purposeful use of two languages which are designed systematically and strategically (Lewis et al., 2012). In translanguaging activities, the input and the output are done in two different languages (Baker, 2001). To exemplify, teachers create learning activities that employ L1 in discussion and target language in writing. Then, this study has further continued by 
Garcia (Garcia, 2009). The study posited that translanguaging is an act performed by bilinguals who draw on their languages to access new languages or to convey the message using more than one language in order to maximize communicative potential (Garcia, 2009).

Additionally, translanguaging emphasizes on flexible use of languages. It suggests that students may gap-fill the words from their L1 with the words that they do not know in their target language (Garcia, 2009). The students may also use a specific word or concept from their L1 because it does not exist in their target language (Garcia, 2009). Such simultaneous use of languages show that languages are not separated but they are drawn to create meaning or to convey the message (Blackledge \& Creese, 2010). They took the most effective words from a single linguistic system to accomplish their intended communication. It is further asserted that they select language features from their overall repertoire that help them fulfill their communicative needs and assert their linguistic and cultural identities (García \& Wei, 2014). Hence, it can be implied that translanguaging goes beyond fluid discursive practices for meaningmaking.

To do with translanguaging pedagogy, the classroom activities promote students to connect their native language use with the new language they learn. One of the examples of is employing students' first language to assist their learning. The classroom highlights on the functions rather than the form and more on the bilingual learning process rather than on its outcomes (Lewis et al., 2012). This scaffolding can take many forms such as explaining a text, translating a vocabulary word, relating an idea to a common L1 saying or for checking comprehension (Alkatheery, 2014; Carroll \& Morales, 2016; Lasagabaster \& García, 2014; Mazak \& Herbas-Donoso, 2015). These activities will facilitate them to gain deeper learning because they are allowed to tap into their full linguistic system. Not only scaffold the students, translanguaging pedagogy establishes space for them where their language choices are valued, accepted and encouraged (Palmer et al., 2014). As a result, the students and the teachers will be able to build rapport, nurture a shared identity and create a positive classroom climate.

In the ELT practice, teachers can provide rigorous instruction and maximize interactions that develop students' language and meaning-making repertoire (García \& Wei, 2014). To implement translanguaging in the classroom, there are some guidance to be adhered which are differentiating among students' levels and adapting instruction to different types of students in multilingual classrooms, building background knowledge, developing understanding, developing and extending new knowledge, critical thinking, crosslinguistic transfer and metalinguistic awareness, cross-linguistic flexibility, identity investment and positionality, and interrogating linguistic inequality and disrupting linguistic hierarchies and social structures (García \& Wei, 2014). Furthermore, there are some strategies that can be implemented in the classroom to support translanguaging in teaching English such as translation, collaborative dialogue, collaborative grouping, reading multilingual texts, thematic units, word walls, sentence starters, cognates, and multilingual vocabulary inquiry (García \& Wei, 2014).

Lastly, in regard to related studies, scholars have grown interest towards the use of two languages in EFL classroom which focuses on two areas namely the use of L1 as scaffolding in EFL classroom and its impacts. To do with L1 as scaffolding in EFL classroom, the studies primarily revealed that L1 assists the learners to learn target language (Aminifard \& Mehrpour, 2019; Bhooth et al., 2014; Dahlberg, 2017; Daniel et al., 2019; Lin, 2015; Zein, 2019). Furthermore, the studies also expose the impacts of the use of two languages on students' proficiency in multilingual classroom(Adamson \& Coulson, 
2015; Daniel et al., 2019; Huang, 2018; Li \& Exley, 2019; Zhang, 2018). They mainly found that the use of two languages will increase outcomes for most students of lower proficiency. Nonetheless, limited studies were found regarding teachers' attitudes towards translanguaging in Indonesian EFL classroom (Rasman, 2018). This dimension appears to be important to be investigated in the context of Indonesian EFL classroom. Therefore, to fill the gap with previous studies, this study was conducted in order to find out teachers' attitudes towards translanguaging in Indonesian EFL classrooms.

\section{RESEARCH METHODS}

This study employed descriptive quantitative approach through survey. In line with this, there were 50 EFL teachers employed in this study who work in different elementary schools in Bandung, Indonesia who filled the questionnaire. The participants consisted of 41 females and 9 males. $75.6 \%$ (38 teachers) of the participants had working experience less than five years while $24.4 \%$ (12 teachers) of them had working experience more than five years. The current study adopted a questionnaire made by Nambisan and Yuvayapan (Nambisan, 2014; Yuvayapan, 2019). It was administered to discover teachers' attitudes towards translanguaging. The items which were included consisted of teachers' general information (gender, years of teaching experience and teachers' native language) and their view about translanguaging which were presented in Likert-Type scale items. There were 20 questions asked to the teachers. The survey was cross-sectional survey and it was administered online by using Google Form. The questionnaire was analyzed by descriptive statistics to calculate the percentages of each Likert-type item in the questionnaires.

\section{RESULTS AND DISCUSSION 3.1. Results}

The survey consisted of 15 questions in total. The questions are presented in two categories namely teachers' background information and teachers' attitudes towards translanguaging. In the first category, teachers' general information is shown.

a. Teachers' general information

The questions which refer to this category starts from question number one until question number four. This study employed 50 participants. They are English teachers in Bandung, Indonesia who teach in different schools. Most of them are females $(82.2 \%, 41$ teachers) and the rest is males $(17.8 \%, 9$ teachers). Their teaching experiences are different. Mainly, $75.6 \%$ (38 teachers) of the participants have been taught less than five years and $24.4 \%$ (12 teachers) of them have gained more than five years of teaching experience. It can be seen from the tables one below.

Further, table three below indicates teachers' native language. Their native

Table 1. Gender

\begin{tabular}{ccc}
\hline \multirow{3}{*}{ Gender } & Female & Male \\
\cline { 2 - 3 } & $\%$ & $\%$ \\
\cline { 2 - 3 } & 82.2 & 17.8 \\
\hline
\end{tabular}

Table 2. Teaching Experience

\begin{tabular}{ccc}
\hline \multirow{2}{*}{$\begin{array}{c}\text { Teaching } \\
\text { experience }\end{array}$} & Less than five years & More than five years \\
\cline { 2 - 3 } & $\%$ & $\%$ \\
\hline
\end{tabular}

language is various. $30.8 \%$ of the participants claimed that their native language is Indonesian. $46.7 \%$ of the participants selected Sundanese as their native language. $15.6 \%$ participants speak Javanese and 8.2\% speak Minang language. 
Table 3. Teachers' Native Language

\begin{tabular}{clcc}
\hline No & Teachers' native language & Percentage (\%) & Number of participants \\
\hline 1. & Indonesian & 30.8 & 15 \\
\hline 2. & Sundanese & 46.7 & 23 \\
\hline 3. & Javanese & 15.6 & 8 \\
\hline 4. & Minang & 8.2 & 4 \\
\hline
\end{tabular}

Afterwards, the table four below their native language. portrays teachers' proficiency rate regarding

Table 4. Teachers' Native Language Proficiency

\begin{tabular}{ccccc}
\hline Coverage & $\begin{array}{c}\text { I only know } \\
\text { a few basic } \\
\text { words and } \\
\text { phrases }\end{array}$ & $\begin{array}{c}\text { I am able to } \\
\text { have limited } \\
\text { conversation on } \\
\text { everyday topics }\end{array}$ & $\begin{array}{c}\text { I am able to } \\
\text { discuss a variety } \\
\text { of topics without } \\
\text { too much trouble }\end{array}$ & $\begin{array}{c}\text { I have no problem } \\
\text { communicating with } \\
\text { native-speakers on a } \\
\text { wide range of topics }\end{array}$ \\
\hline Scale & 1 & 2 & 3 & 4 \\
\hline Percentage (\%) & 2.2 & 2.2 & 44.5 & 51.1 \\
\hline $\begin{array}{c}\text { Number of } \\
\text { Participants }\end{array}$ & 1 & 1 & 22 & 26 \\
\hline
\end{tabular}

From the scale one to four, $95.6 \%$ (48 teachers) of the participants stated that they are proficient in theirnativelanguage. Itmeans thatthey have no difficulties when communicating with the same native-speakers of their language on a wide range of topics. Only two participants $(4.4 \%)$ who have limited vocabularies of their native language and performed limited conversation on everyday topics. The general information of the teachers that have been presented previously is used to prove that Indonesia is a multilingual country where national language and vernacular languages exist to show diversity.
b. Teachers' attitudes towards translanguaging

The questions in the second section of the questionnaire aimed to examine teachers' attitudes regarding translanguaging in EFL classrooms. These questions were designed to reflect teachers' attitudes in their teaching practices which cover their language choice and translanguaging use in EFL classrooms. The results and discussion of this topic are presented below.

1. Language choice in English class

The first question was addressed to figure out the primary language of instruction in Indonesian EFL classrooms. The findings expose that most participants $(57.8 \%, 30$ teachers) chose English and Indonesian language to be employed in the classroom. Then, 12 teachers $(24.4 \%)$ selected English, Indonesian and local language to be used in the classroom. $17.8 \%$ ( 8 teachers) preferred to teach English-only in their English classrooms.

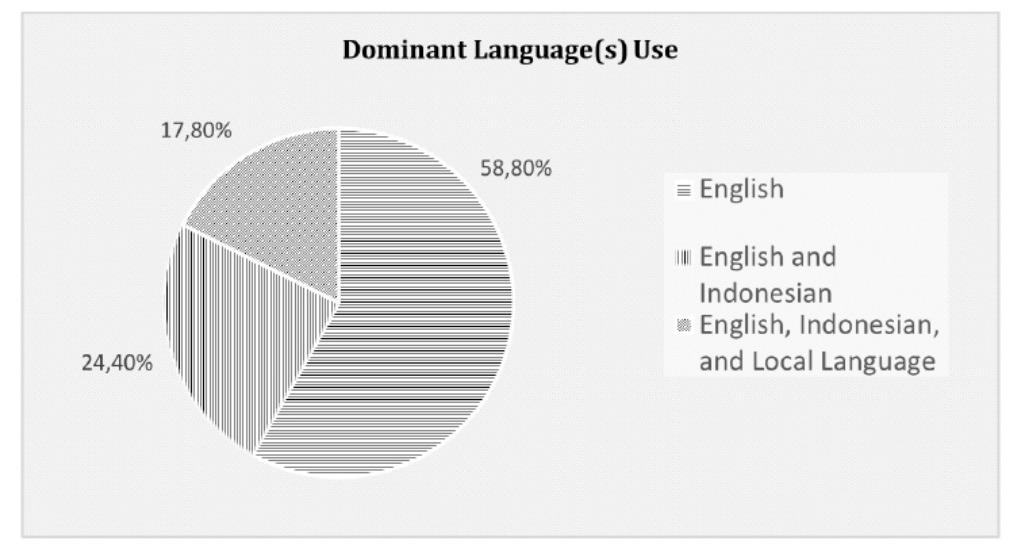

Figure 1. Dominant Language(S) in the Classroom 
The figure above reveals that the language choices selected by the teachers in their English classroom represent their perspective whether they prefer the class to use monolingual approach or bilingual approach. In this case, instead of choosing English-only instruction, most of the teachers preferred to employ Indonesian as well as local language to be used in English classroom. This evidence suggests that L1 could be used alongside with English in EFL classrooms and the teachers were aware of its advantages since they implemented it.

The explanation above is pursued by the questions number six until ten. In question number six, the teachers mostly used English to greet the students in the beginning and at the end of the lesson. The figure is shown below.

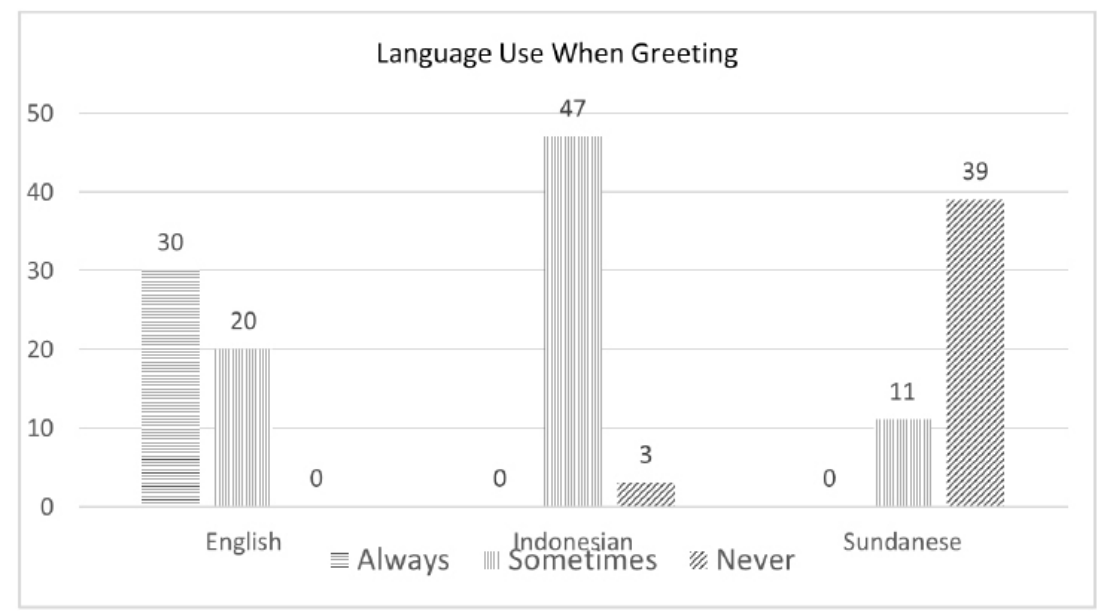

Figure 2. Language Choice in Greeting

There are 30 teachers who always used English to greet the students and 20 of them greeted the students sometimes. Additionally, the figure 2 shows that Indonesian and other vernacular languages were still chosen to greet the students although the occurrence was not as often as English. It can be seen that 47 and 11 teachers occasionally used Indonesian and
Sundanese to greet the students. When the teachers greet the students in the language they are familiar of, it helps the students to minimize their anxiety since they are not proficient enough in the target language and to create a less-threatening classroom.

Furthermore, the language choice used by the teachers was also reflected in the translation situation.

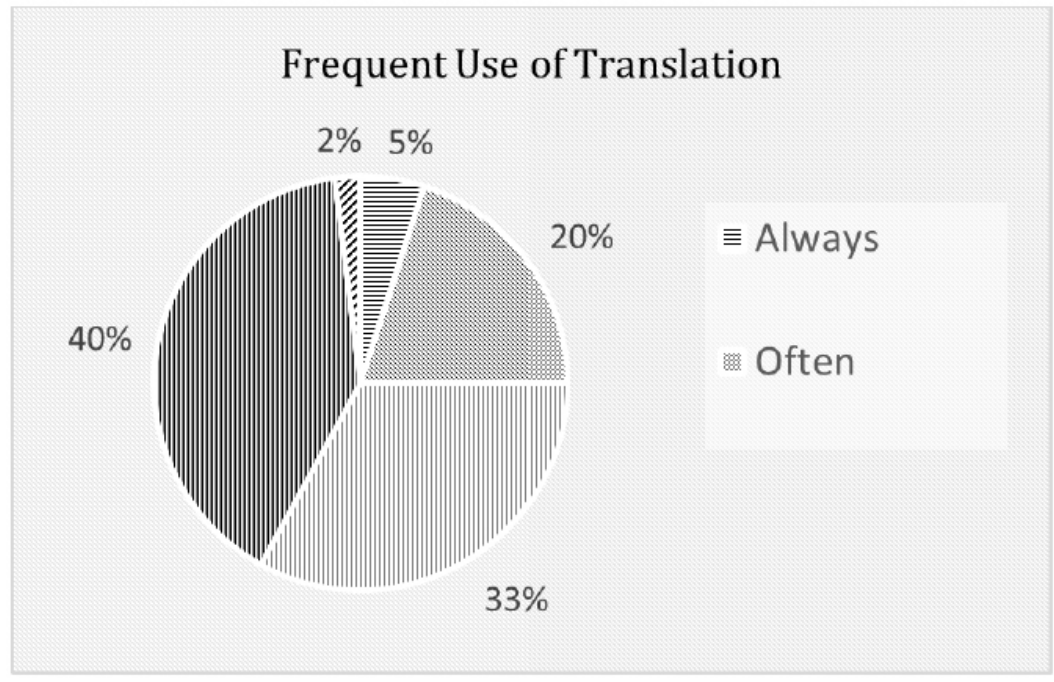

Figure 3. Language Choice in Translation 


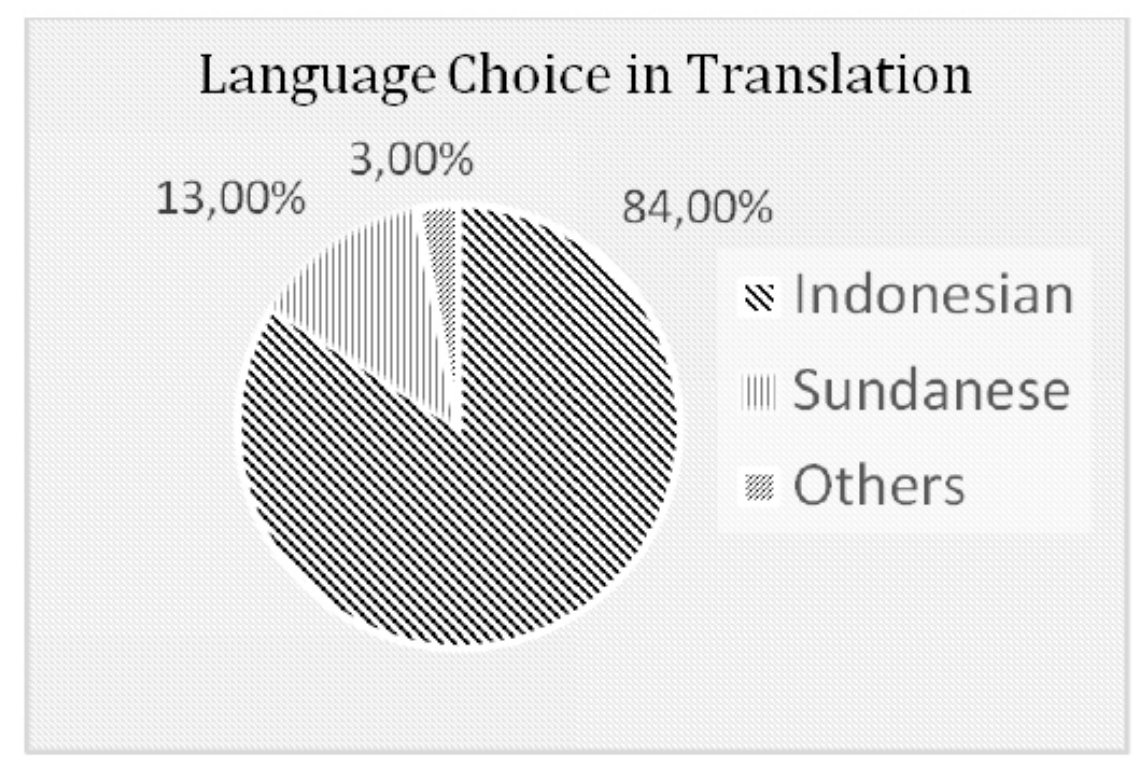

Figure 4. Language Choice in Translation

Most of the teachers (93\%, 46 teachers) agreed that they did translation in their classroom. The language that was used primarily Indonesian by $84 \%$. Therefore, as a strategy for language learning, Indonesian EFL teachers acknowledged that translation activities can assist the students to accommodate their learning and to develop their communicative competence.

Additionally, the occurrence of language choice chosen by the teachers can be seen in teachers' dialogue with the students.

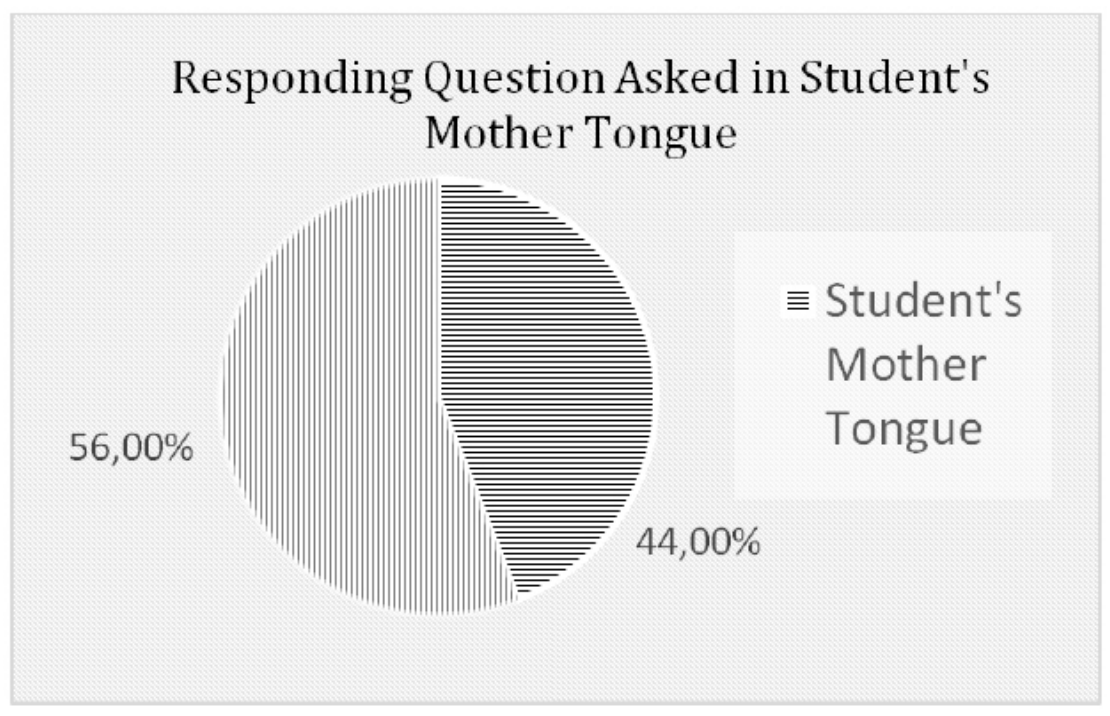

Figure 5. Language Choice in Dialogue

When being asked what language the teachers typically respond when the student asked them in their mother tongue, half of the participants $(56 \%, 28$ teachers) answered English. The rest of the participants answered in students' mother tongue again $(44 \%, 22$ teachers). Those who chose to respond it in English are assumed to maximize the use of English in the classroom as desired. Meanwhile, the teachers who selected to respond in students' mother tongue is argued to perceive the phenomenon as a natural reference point for learners; thus, it will be appropriate to use students' mother tongue to explain the activities. 
In line with this, when the teachers asked a question in the target language, mainly the teachers expected the students to answer in target language.

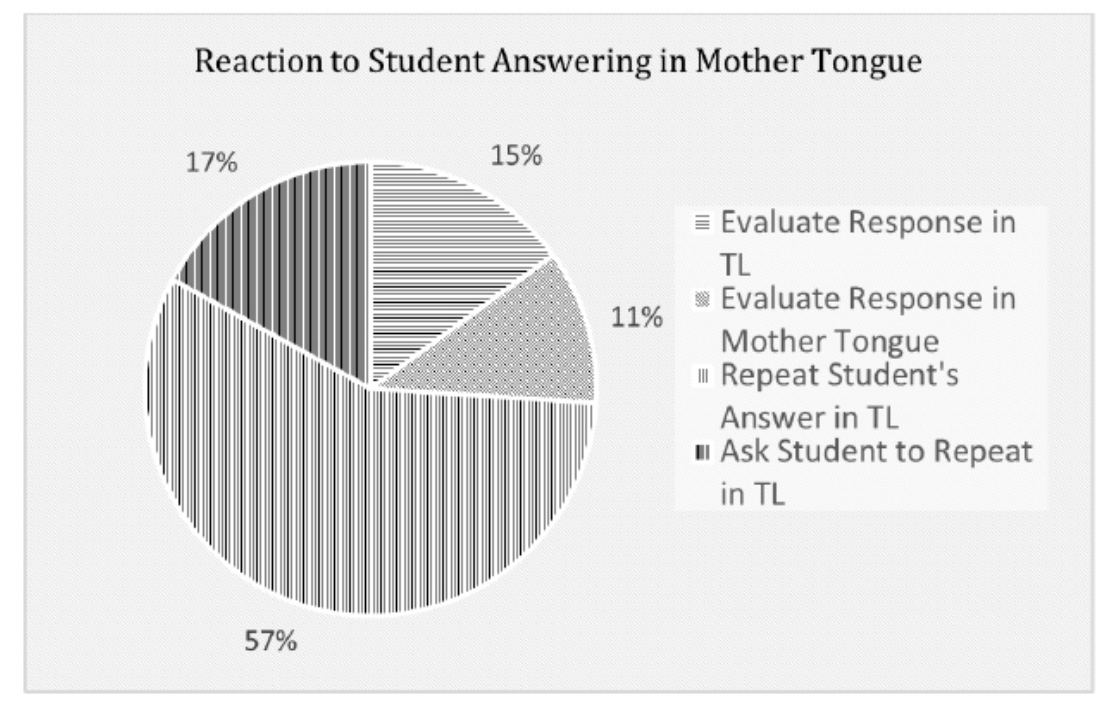

Figure 6. Language Choice in Dialogue

From the figure above, only five teachers $(11 \%)$ evaluate response in the mother tongue of the students. The findings seem interesting since it is contradictory to what the teachers stated earlier.

\section{Uses of translanguaging}

The questions from eleven to sixteen are used to find the uses of translanguaging in EFL classroom which involve teachers' perception in general, the importance of translanguaging, and the frequency of translanguaging use in the classroom.

Regarding to the question number eleven, it elicited teachers' perception of the use of Indonesian and vernacular language in English classroom. The dominance of the participants $(78 \%, 39$ teachers) believed that the incorporation of Indonesian language and local language are beneficial in the English language classroom in foreign language context. It can be seen in the Figure 7 below.

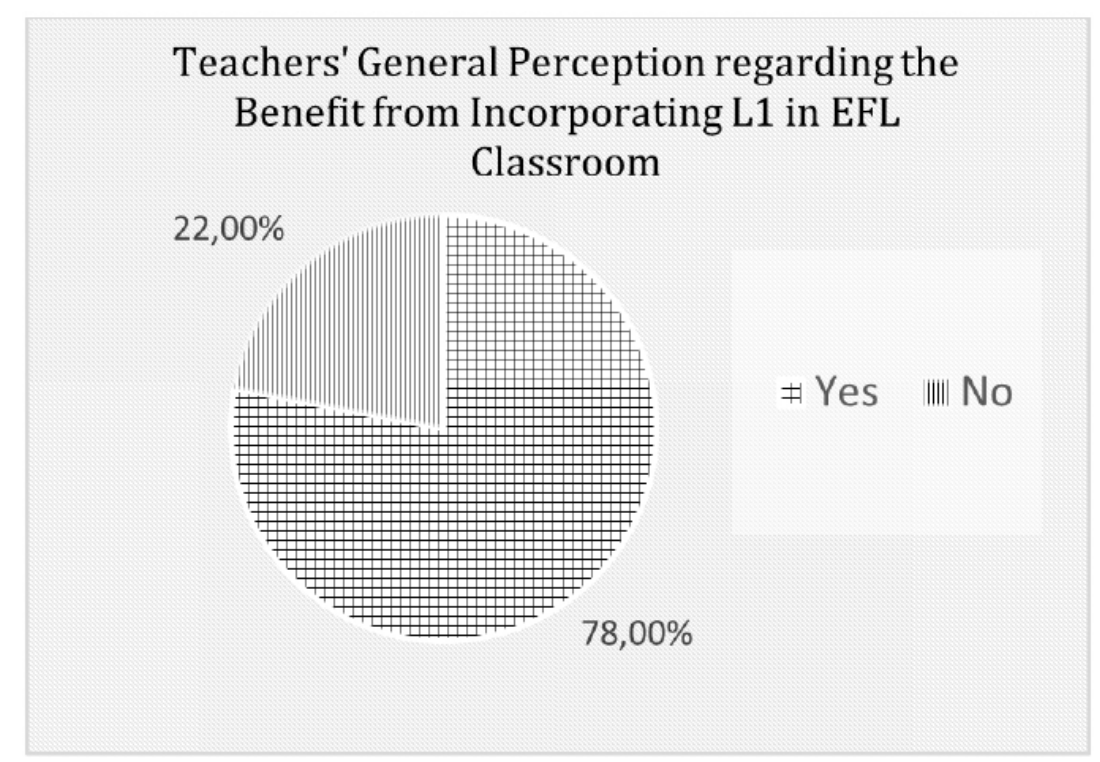

Figure 7. General Perception of Translanguaging

The second analysis deals with the importance of translanguaging which refers to questions number twelve and thirteen. The findings can be seen in the table below. 
Table 5. Importance of Translanguaging

How important is it for teachers to use Indonesian and local language in the following situations?

\begin{tabular}{|c|c|c|c|c|c|c|c|c|c|}
\hline & $\begin{array}{c}\text { To } \\
\text { explain } \\
\text { concepts }\end{array}$ & $\begin{array}{l}\text { To describe } \\
\text { vocabulary }\end{array}$ & $\begin{array}{c}\text { To give } \\
\text { directions }\end{array}$ & $\begin{array}{c}\text { For } \\
\text { classroom } \\
\text { management }\end{array}$ & $\begin{array}{c}\text { To give } \\
\text { feedback } \\
\text { to the } \\
\text { students }\end{array}$ & $\begin{array}{c}\text { To } \\
\text { praise } \\
\text { students }\end{array}$ & $\begin{array}{c}\text { To build } \\
\text { bonds } \\
\text { with the } \\
\text { students }\end{array}$ & $\begin{array}{c}\text { To } \\
\text { quickly } \\
\text { clarify } \\
\text { during } \\
\text { activities }\end{array}$ & $\begin{array}{c}\text { To help } \\
\text { lower } \\
\text { proficiency } \\
\text { students }\end{array}$ \\
\hline & $\%$ & $\%$ & $\%$ & $\%$ & $\%$ & $\%$ & $\%$ & $\%$ & $\%$ \\
\hline Indonesian & 72 & 66 & 42 & 30 & 48 & 16 & 68 & 68 & 90 \\
\hline $\begin{array}{c}\text { Local } \\
\text { language }\end{array}$ & 12 & 20 & 12 & 10 & 14 & 14 & 48 & 28 & 44 \\
\hline
\end{tabular}

It is evident from the Table 5 that EFL teachers believed that Indonesian and vernacular language served important functions in the classroom moderately. The functions are to explain concepts, to describe vocabulary, to give directions, to manage the classroom, to give feedback to the students, to praise students, to build bonds with the students, to clarify during the activities and to help lower proficiency students. It can also be seen that Indonesian was more prevalent to be used in the classroom rather than vernacular language. Nonetheless, it does not mean that vernacular language does not have particular function in the classroom. Then, the highest percentage is on the item to help lower proficiency students in both languages by $90 \%$ for Indonesian and $44 \%$ for vernacular language. This implies that translanguaging could scaffold lower proficiency students to learn English.

Afterwards, the next questions, 14 and 15, asked the participants regarding the frequency of translanguaging use in the classroom. There are six items which are categorized into three groups namely discussion, participation, and treatment of subjects unrelated to tasks. To do with the first group, it deals with discussion which includes 'to discuss content or tasks in small groups', 'to answer teachers' questions' and 'to brainstorm during class activities.

Table 6. Discussion by Using Translanguaging

How often do you observe or encourage the use of Indonesian in the
classroom for the following purposes?

The table portrayed that both Indonesian and local language were used in EFL classroom for discussion. There were only a smaller percentage of teachers who used local language $(8 \%, 10 \%, 10 \%)$ in the classroom. Besides, it illustrates that in Indonesian EFL classroom, English, Indonesian and vernacular language are used flexibly. It is argued that it can maintain the discussion or tasks in the classroom.

After that, the participation of the students is also viewed by the teachers from the lens of translanguaging. The items which are analyzed include 'to promote assistance to peers during activity' and 'to enable participation by lower proficiency students. It is found that the teachers observed their students employed Indonesian (44\% and $72 \%$ ) more than vernacular language (20 and $18 \%$ ) when they assisted their peers during classroom activity especially the lower proficiency students. 
Table 7. Participating by Using Translanguaging

How often do you observe or encourage the use of Indonesian in the classroom for the following purposes?

\begin{tabular}{lcc}
\hline \multirow{2}{*}{ Items } & Indonesian & \multicolumn{2}{c}{ Local language } \\
\cline { 2 - 3 } & \multicolumn{2}{c}{} \\
\hline To promote assistance to peers during activity & 44 & 20 \\
\hline To enable participation by lower proficiency students & 72 & 18 \\
\hline
\end{tabular}

The use of translanguaging, in this case, revealed that it leads to students' L2 learning.
Lastly, to do with the treatment of subjects unrelated to tasks, the item covers 'to explain problems not related to content'.

Table 8. Treatment of Non-Subject Related Task

\begin{tabular}{|c|c|c|}
\hline \multicolumn{3}{|c|}{$\begin{array}{l}\text { How often do you observe or encourage the use of Indonesian and local } \\
\text { language in the classroom for the following purposes? }\end{array}$} \\
\hline \multirow{2}{*}{ Items } & Indonesian & Local language \\
\hline & \multicolumn{2}{|c|}{$\%$} \\
\hline To explain problems not related to content & 52 & 14 \\
\hline
\end{tabular}

Table 8 indicates that teachers encouraged the use of Indonesian and vernacular language in the classroom. The percentage of local language is much lower $(14 \%)$. Nonetheless, from the table, it can be figured out that the use of both languages in EFL classroom were still needed despite it does not related to content or the subject being taught.

\subsection{Discussion}

The findings revealed that the teachers in the present study were already multilinguals since the languages that they acquired were more than two languages. They were able to use vernacular language, national language and English language. Furthermore, they also showed positive attitudes towards translanguaging. It can be seen from the language choice that they used and the utilization of translanguaging in the classroom. This suggests that the teachers were aware of the benefits of translanguaging in EFL classroom. Therefore, the findings that have been mentioned earlier are presented in the discussion below.

Multilingual teachers are important in multilingual classroom. In the present study, it is found that the teachers were already multilinguals. It is implied that the teachers were able to communicate with the samenative speakers of their language on a wide range of topics without any difficulties. In line with this, another study discovered that the bi/multi-lingual language use will benefit the students (Nursanti, 2016). There are six benefits which were revealed in the study. First, it assists the students to understand English lesson (Nursanti, 2016). Second, it helps them to understand new vocabularies in English (Nursanti, 2016). Third, it can help them to do exercises (Nursanti, 2016). Fourth, it helps them to ask and answer something during the class (Nursanti, 2016). Fifth, it assist them to read something in English correctly, (Nursanti, 2016). Lastly, it makes them feel comfortable during the class (Nursanti, 2016).

The present study also indicated that the teachers showed positive attitudes towards translanguaging in their English classroom which can be seen from the language choice and the utilization of translanguaging. To do with the language choice, it is found that the use of vernacular language and national language were still prevalent in their English classroom (Androula \& Marina, 2013; Julianti et al., 2016) . They figured out that students' L1 were more prevalent to be used in EFL classroom because it assisted the students to learn target language (Androula \& Marina, 2013; Julianti et al., 2016). Hence, it can be denoted that using L1 in EFL classroom is 
undeniable and it provides specific language function to facilitate learning.

Furthermore, the findings show that the teachers used students' L1 to greet the students. Similarly, this case is also depicted in a study by Al-Ta'ani (2019). The study found that the teachers used Arabic as their L1 in EFL classroom to greet the students (Al-Ta'ani, 2019). In line with this, it is argued that greetings strategies applied by the teachers could establish and maintain social relations. Hence, translanguaging does not only provide linguistic function but it also offers affective function in the classroom (Bourton \& Rajendram, 2019).

One of translanguaging activities in the classroom which was conducted by the teachers was employing translation. According to Mohamed (2014), translation activities helped teachers in their teaching and facilitated students learning in EFL classroom. He further asserted that translation could be used for checking students' understanding, clarifying the meanings of vocabulary units and comparing linguistic units (Mohamed, 2014). In the same vein, it is strongly believed that translation can be used for increasing learners' communicative competence and for understanding semantic relationship, language functions, information, and discourse (Al-Musawi, 2014).

The majority of the participants selected the use of English in the classroom discussion was important. Corresponding to this, a study indicated that some EFL teachers believed that during the process of teaching and learning, the maximum exposure of English should be given because EFL students did not use much English outside the classroom (Manara, 2007). Meanwhile, the teachers who selected to respond in students' mother tongue is argued to perceive the phenomenon as a natural reference point for learners; thus, it will be appropriate to use students' mother tongue to explain the activities. The students' mother tongue can become a valuable resource of language knowledge that the teachers can employ to the classroom to facilitate them learning English (Cook, 2001). Thus, this is similar to what has been studied by Manara (2007) that most of the teachers believed that the use of English is desirable; however, the presence of students' mother tongue is undeniable in EFL classroom.

Regarding the use of translanguaging in the classroom, it covers teachers' perception in general, the importance of translanguaging, and the frequency of translanguaging use in the classroom. Dealing with teachers' perception, it is revealed that they mainly found the integration of national language and vernacular language beneficial in their classroom whilst the rest chose English-only instruction. As Storch and Wigglesworth (2003) claim that L1 could be a useful tool for gaining control over the task and working at a higher cognitive level. Then, to do with the importance of translanguaging, the findings indicated that translanguaging was important to be implemented in English classroom. The most apparent importance of translanguaging was to assist lower proficiency students. This implies that translanguaging could scaffold lower proficiency students to learn English which is relevant to Yuvayapan (2019). She stated that when translanguaging occurs in the classroom, lower level proficiency students could use this opportunity to understand the lesson and to participate in the classroom (Yuvayapan, 2019).

To do with translanguaging use in the classroom, the present study found that it can be used to maintain the discussion, to engage participation, and to treat subjectunrelated task. First, it was revealed that the flexible use of language can maintain the discussion in the classroom. In line with this, the use of translanguaging in the discussion activity elucidates that L1 is considered to be a powerful tool to control the tasks and to discuss the content in the classroom (Pinto, 2020). Second, translanguaging can be used to engage students' participation. In line with this, it is mentioned by Aoyama (2020) that students' awareness towards the use of L1 as established by the teachers will facilitate the learning process. Students will use L1 to provide explanations about unknown words and phrases in English which they 
thought will be difficult to be understood by their peers (Aoyama, 2020). They took this consideration regarding their peers' linguistic resources and communicative competence and employed the language which is understandable between them and their peers (Aoyama, 2020). Third, translanguaging can be used to treat subject-unrelated task. In this case, it is explained by $\mathrm{Li}$ and Luo (2017) that translanguaging can be used in EFL classroom to build rapport with the students. It is also confirmed by Marsakawati (2017) that it will build good relationship because the effort of using L1 in the classroom is considered to make them less threatened to learn English in the classroom and to reduce their anxiety at the same time.

\section{CONCLUSIONS}

In conclusion, the survey reveals that most of Indonesian EFL teachers employed translanguaging in the classrooms. Furthermore, they regarded it as important because it served many functions that helped their students to learn English and assisted the teachers as pedagogical tool. The results also demonstrate that most of the teachers flexibly use the language since they used English, Indonesian and vernacular language in the EFL classrooms. It implies that the teachers are already creating space for their multilingual students to draw all linguistic repertoires in order to mediate them learning the target language.

The majority of the teachers were aware of the benefits offered by translanguaging which can be seen from the language choice, the importance of translanguaging, and the uses of translanguaging. The findings illustrated that the teachers who chose Indonesian and vernacular languages in translation activity were able to value students' mother tongue. Meanwhile, the teachers who used English-only in their classroom are assumed to maximize exposure in English. Additionally, it depicts that Indonesian was more prevalent to be chosen by the teachers rather than vernacular language. Nonetheless, it must be noted that vernacular language was still used in EFL classrooms which offers some benefits; one of them is helping lower proficiency students. In regard to the importance of translanguaging, it assisted the teachers to explain concepts, to describe vocabulary, to give directions, to manage the classroom, to give feedback to the students, to praise students, to build bonds with the students, to clarify during the activities and to help lower proficiency students. Lastly, dealing with the uses of translanguaging, the results showed that it can be used for discussion, participation and treatment of subjects unrelated to tasks.

There are some suggestions which are offered for future researchers who are interested in this topic. First, this research is limited to teachers' attitudes only. Thus, future study must involve how translanguaging is practiced in EFL classrooms. Furthermore, since this research focuses on the teachers, future studies must attempt to discover how translanguaging is perceived and employed by the students. Finally, future research is suggested to investigate the challenges of translanguaging faced by the teachers in EFL classrooms.

\section{REFERENCES}

Adamson, J., \& Coulson, D. (2015). Translanguaging in English academic writing preparation. International Journal of Pedagogies and Learning, 10(1), 24-37. https://doi.org/doi:10.1080/22040552.2015.1084674.

Al-Musawi, N. (2014). Strategic use of translation in learning English as a foreign language (EFL) among Bahrain university students. Comprehensive Psychology, 3(10), 1-10. https://doi.org/10.2466/10.03.it.3.4.

Al-Ta'ani, M. (2019). The use of Arabic (L1) in the EFL classroom: How do Umm Al-Quwain teachers and students perceive it? International Journal of Contemporary Education, 2(2), 1-26.

Alkatheery, E. (2014). Functions of teacher code-switching in a Saudi EFL classroom: A case study. Perspectives, 22(3), 18-23.

Aminifard, Y., \& Mehrpour, S. (2019). Mother tongue use in young Iranian EFL learners' classroon: Helpful scaffold or debilitating crutch? The Reading Matrix: An International Online Journal, 19(2), 77-85. 
Androula, Y., \& Marina, M. (2013). Language choices by teachers in EFL classroom in Cyprus: Bidialectism meets bilingualism with a call for teacher training programmes in linguistic variation. Teacher Development, $17(2), 214-227$.

Aoyama, R. (2020). Exploring Japanese high school students' 11 use in translanguaging in the communicative EFL classroom. TESL-EJ, 23(4), 1-18.

Baker, C. (2001). Foundations of bilingual education and bilingualism (3rd ed.). Clevedon: Multilingual Matters.

Bhooth, A., Azman, H., \& Ismail, K. (2014). The role of the L1 in scaffolding tool in the EFL classroom. Social and Behavioral Science, 118, 76-84.

Blackledge, A., \& Creese, A. (2010). Translanguaging in the bilingual classroom: A pedagogy for learning and teaching? The Modern Language Journal, 94(1), 103-115.

Bourton, J., \& Rajendram, S. (2019). Translanguaging-as-resource: University ESL instructors' language orientations and attitudes toward translanguaging. TESL Canada Journal, 36(1), 21-47.

Carroll, K., \& Morales, S. (2016). Carroll, K. S., \& Sambolín Morales, A. N. (2016). Using university students' L1 as a resource: Translanguaging in a Puerto Rican ESL classroom. , 39(3-4), 248-262. Bilingual Research Journal, 39(3-4), 248-262.

Cook, V. (2001). Using the first language in the classroom. Canadian Modern Language Review, 57(3), 402-423.

Dahlberg, A. (2017). Translanguaging as a scaffolding structure in a multilingual group studying English in Sweden (University of Gävle). Retrieved from http://www.diva-portal.org/smash/get/diva2:1083686/ FULLTEXT01.pdf.

Daniel, S., Jimenez, R., Pray, L., \& Pacheco, M. (2019). Scaffolding to make translanguaging a classroom norm. TESOL Journal, 10(1), 1-14.

Garcia, O. (2009). Education, multilingualism and translanguaging in the 21 st century. In A. K. M. and M. P. T. Skutnabb-Kangas, R. Phillipson (Ed.), Social Justice Through Multilingual Education. Clevedon: Multilingual Matters.

García, O., \& Wei, L. (2014). Translanguaging: Language, bilingualism and education. https://doi. org/10.1057/9781137385765.

Huang, J. (2018). Translanguaging in a Birmingham Chinese complementary school: Ideology and identity. In G. Mazzaferro (Ed.), Translanguaging as Everyday Practice (pp. 69-86). https://doi.org/doi.org/10.1007/9783-319-94851-5_5.

Julianti, R., Atmowardoyo, H., \& Mahmud, M. (2016). University English teachers and students' perceotions of language choices in EFL classroom. ELT Worldwide, 3(2), 204-220.

Lasagabaster, D., \& García, O. (2014). Translanguaging: towards a dynamic model of bilingualism at school. Cultura y Educacion, 26(3), 557-572.

Lewis, G., Jones, B., \& Baker, C. (2012). Translanguaging: Developing its conceptualisation and contextualisation. Educational Research and Evaluation, 18(7), 655-670. https://doi.org/https://doi.org/10.1080/13803611 .2012.718490.

Li, M., \& Exley, B. (2019). Benefits of translanguaging and transculturation exchanges between international higher degree research students and English medium research supervisors. In Multilingual Education Yearbook (pp. 121-135). Cham: Springer.

Li, S., \& Luo, W. (2017). Creating a translanguaging space for high school emergent bilinguals. The CATESOL Journal, 29(2), 139-162.

Lin, A. (2015). Conceptualising the potential role of L1 in CLIL. Language, Culture and Curriculum, 28(1), 74-89.

Manara, C. (2007). The use of L1 support: Teachers' and Students' opinions and practices in an Indonesian context. The Journal of AsiaTEFL, 4(1), 145-178.

Marsakawati, N. (2017). Language choice in multilingual context: The use of L1 in the hospitality English courses. Journal of English Education, Literature, and Culture, 2(1), 263-272.

Mazak, C., \& Herbas-Donoso, C. (2015). Translanguaging practices at a bilingual university: a case study of a science classroom. Journal of Bilingual Education \& Bilingualism, 18, 698-714.

Mohamed, J. (2014). Use of translation in the classroom by EFL teachers in Libya. Arab World English Journal, (3), $27-40$.

Nambisan, K. (2014). Teachers' attitudes towards and uses of translanguaging in English language classrooms in Iowa. Iowa State University.

Nursanti, Y. (2016). Students' perception of teacher's bilingual language use in an English classroom. Journal of 
English and Education, 4(1), 159-176.

Palmer, D., Martinez, R., Mateus, S., \& Henderson, K. (2014). Reframing the debate on language separation: Toward a vision for translanguaging pedagogies in the dual language classroom. The Modern Language Journal, 98(3), 757-772.

Pinto, J. (2020). Chinese teachers' attitudes towards translanguaging and its uses in Portuguese foreign language classroom. Theory and Practice of Second Language Acquisition, 6(1), 11-30.

Rasman, R. (2018). To translanguage or not to translanguage? The multilingual practice in an Indonesian EFL classroom. Indonesian Journal of Applied Linguistics, 7(3), 687-694. https://doi.org/doi: 10.17509/ijal. v7i3.9819.

Storch, N., \& Wigglesworth, G. (2003). Is there a role for the use of the L1 in an L2 setting? TESOL Quarterly, 37(4), 760-770.

Williams, C. (1996). Secondary education: Teaching in the bilingual situation. In C. Williams, G. Lewis, \& C. Baker (Eds.), The language policy: Takings stock. Llangefni: CAI.

Yuvayapan, F. (2019). Translanguaging in EFL classrooms: Teachers' perceptions and practices. Journal of Language and Linguistic Studies, 15(2), 678-694.

Zein, S. (2019). English, multilingualism and globalisation in Indonesia. English Today, 35(1), 48-53. https://doi. org/10.1017/S026607841800010X

Zhang, M. (2018). Collaborative writing in the EFL classroom: The effects of L1 and L2 use. System, 76, 1-12. 